\title{
APRESENTAÇÃO \\ DOSSIÊ: ENSINO DE HISTÓRIA, HISTÓRIA DAS MULHERES E DESIGUALDADES SOCIAIS NO BRASIL
}

\author{
Organizadoras: \\ Kênia Érica Gusmão Medeiros ${ }^{1}$ \\ Gilmária Salviano Ramos ${ }^{2}$ \\ Paula Faustino Sampaio ${ }^{3}$
}

O dossiê Ensino de história, história das mulheres e desigualdades sociais no Brasil é um convite a um presente e um futuro feministas. A obra conta com um conjunto de ações concretas, propositivas e imediatas dos ensinos de história dentro do campo da história das mulheres e dos estudos de gênero. De norte a sul, de oeste a leste do Brasil, o dossiê em tela recebeu artigos que são atravessados pelas discussões acerca dos marcadores sociais de gênero, de classe e de raça. São contribuições dos fazeres da história que permeiam temas e problemáticas distintas. Além disso, abrangem uma diversidade de fontes documentais - legislações, livros didáticos, literatura, oficinas temáticas, literatura de cordel, história oral, fontes digitais e iconográficas, entre outras -, cotejando metodologias de pesquisa e dos ensinos de história. Trata-se de uma riqueza que amplia a perspectiva de gênero e não se encerra em si mesma, abre caminhos e condições de possibilidade para futuras reflexões, relacionando ensino, pesquisa e extensão - tripé caro aos institutos federais e às universidades-, bem como os desafios para a Educação Básica.

\footnotetext{
1 Doutora em História pela Universidade Federal de Goiás - UFG (2019). Mestre em História pela Universidade de Brasília - UnB - (2011). Graduada em História pela Universidade Estadual de Goiás - UEG- (2008).Atualmente docente do quadro do Instituto Federal de Educação, Ciência e Tecnologia de Goiás (IFG).

2 Doutorado em História Cultural pela Universidade Federal de Santa Catarina (2015), com período sanduíche na École des Hautes Études en Sciences Sociales em Paris (2013). Mestrado em História pela Universidade Federal de Pernambuco (2009). Graduação em História pela Universidade Federal de Campina Grande (2006). Professora Visitante do Departamento de História da Universidade Federal de Viçosa/MG.

${ }^{3}$ Graduada em Licenciatura em Historia pela Universidade Federal de Campina Grande (2006) e mestre em História pela Universidade Federal de Pernambuco (2009). Atualmente, é Professora Assistente II da Universidade Federal de Mato Grosso, Campus Rondonópolis e cursa doutorado em História pelo PPGH/Universidade Federal da Grande Dourados.
} 
Dossiê: Ensino de História, História das Mulheres e Desigualdades Sociais no Brasil

Dentro da perspectiva do engajamento militante e de mobilização política, o dossiê aborda vozes marginalizadas e invisibilizadas pela história, tais como a de Dandara dos Palmares e a representação de mulheres negras em dois livros didáticos do Ensino Fundamental. Vidas ressignificadas pela educação, pela história das mulheres e pela história pública mantêm o vínculo entre o feminismo e potencialidades de um ensino posicionado. Entre avanços e desafios, as ações do Programa Institucional de Bolsas de Iniciação à Docência (Pibid) na formação inicial das professoras para o exercício da docência inauguram uma estratégia política por meio do acesso à educação formal, incluindo igualdade e senso de justiça social.

É precisamente por meio do ensino de história e do combate à violência de gênero no Brasil contemporâneo que se assume a responsabilidade de erradicar a violência sistêmica e estrutural. A esse respeito, as lutas políticas e sociais por meio da educação assumem papel fundamental. O dossiê é norteado por caminhos reflexivos por entender que é possível operacionalizar os feminismos partindo das margens do ensino de história, corroborando com as discussões que vêm sendo desencadeadas desde a década de 1980, pautadas pela ideia de que não somente as mulheres brancas, da classe média e de países do Norte Global produzem história.

Em se tratando do Brasil, presenciam-se feminismos plurais e transdisciplinares que emergem nos entre-lugares sociais e políticos que compõem o escopo deste dossiê. Outrossim, os feminismos mobilizados por meio dos artigos se mostram potencializadores de críticas às desigualdades sociais e às discriminações das diferenças. Nesse sentido, pensar as relações de gênero por meio de oficinas temáticas se propõe como uma perspectiva de discussão das práticas históricas e sociais alicerçadas no patriarcado e no racismo estrutural secular. Construindo caminhos, trilhando possibilidades de ensinar histórias no chão das escolas, professoras e estudantes enfrentam os silêncios que persistem na Base Nacional Comum Curricular do Ensino Médio (BNCCEM), nos livros didáticos e em outros documentos normatizadores dos ensinos, defendendo uma pedagogia feminista voltada para um mundo justo com equidade de gênero. 


\section{HISTÓRIA}

Dossiê: Ensino de História, História das Mulheres e Desigualdades Sociais no Brasil

Por fim, esse espaço de reflexão crítica é fruto da acolhida que a chamada do dossiê recebeu. Foram 92 artigos submetidos a avaliação que sinalizam a potencialidade dos debates relacionando ensino de história, história das mulheres e marcadores sociais; e, sobretudo, evidenciam o compromisso de professoras e estudantes no enfrentamento cotidiano da estrutura de violência de gênero. Como reconhecimento de sua latência, o dossiê foi agraciado pela entrevista inédita da historiadora e feminista Joana Maria Pedro, da Universidade Federal de Santa Catarina (UFSC).

A todas, dedicamos o nosso agradecimento pelo trabalho e pelas inspirações! 